\title{
Prescrição e procedimento dos créditos não tributários*
}

\section{Procedure and limitation period of state's credit}

\author{
Juliano Heinen**
}

\section{RESUMO}

Os créditos não tributários constituem receitas de capital que não podem ser renunciadas. Contudo, em muitas situações, não existe legislação local ou regional que discipline a matéria, não sendo previsto o procedimento administrativo para apurar a referida receita, nem mesmo prazos de prescrição e/ou de decadência aplicáveis à espécie. Assim, diante dessa conjuntura, necessário seja diagnosticada a forma de se cobrar os valores oriundos dessa relação jurídica, bem como qual o período que pode ser cobrado e que não está afetado pela prescrição e/ou decadência, quando inexistem normas legais específicas.

\section{PALAVRAS-CHAVE}

Créditos não tributários estaduais - prazo de prescrição - procedimento

* Artigo recebido em 6 de setembro de 2013 e aprovado em 28 de novembro de 2013.

** Mestre em direito pela Universidade Santa Cruz do Sul (Unisc). Ministra aulas na Universidade de Caxias do Sul (Extensão), Universidade do Vale do Rio dos Sinos (Unisinos) (pós-graduação), na Faculdade IDC (Extensão e Pós-Graduação), na Escola Superior da Magistratura Federal (Esmafe), na Fundação Escola Superior da Defensoria Pública (Fesdep), na Escola Superior da Advocacia Pública (Esapergs), no Curso Verbo Jurídico. Atualmente, desempenha as funções de procurador do estado do Rio Grande do Sul. Procuradoria-Geral do Estado do Rio Grande do Sul. Porto Alegre, Rio Grande do Sul, Brasil. E-mail: julianoheinen@hotmail.com. 


\section{ABSTRACT}

State's credits are capital receipts that can not be waived. However, in many situations, there is no regional or local legislation that governs the matter not being provided the administrative procedure to determine the aforementioned prescription, even periods of limitation and / or decay applicable to the species. So, faced with this situation, the form must be diagnosed to collect the amounts arising from this legal relationship, and which period can be charged and is not affected by prescription and / or decadence, when there is no specific legal provisions.

\section{KEYWORDS}

State's credit - limitation period - procedure

\section{Introdução}

No âmbito federal, a União editou a Lei federal no 9.636/1998, que disciplinou, entre outras matérias, a cobrança dos créditos não tributários, como aqueles derivados do uso de bens públicos por particulares. Já nas administrações públicas dos outros entes da Nação (estados, Distrito Federal e municípios) não necessariamente existe legislação local ou regional que discipline a matéria. Logo, não é previsto procedimento administrativo para apurar a referida receita, nem mesmo prazos de prescrição e/ou de decadência aplicáveis à espécie.

Assim, diante dessa omissão legislativa local e regional, importante diagnosticar a forma de se cobrar os valores oriundos desta relação jurídica, bem como qual o período que pode ser arrecadado e que não está afetado pela prescrição e/ou decadência, quando inexistem normas legais específicas tratando do tema. Impõe-se, a meu ver, a partir de uma verdadeira interpretação sistemática, saber qual a fonte normativa a se aplicar à espécie, ou seja, qual a regra de prescrição aplicável nesta situação, caso ausente norma estadual, municipal ou distrital a regular a matéria.

\section{Da forma de cobrança dos créditos não tributários}

Para definir a forma de cobrança dos créditos não tributários, oriundos, por exemplo, da exploração onerosa de bens públicos, deve-se, antes de tudo, 
ter bem clara qual é a natureza dessa receita. Veja que a exata noção a respeito da relação de direito material incidente é condição para se saber as medidas processuais que dela derivam. Afinal, a pretensão de direito processual é um espelho da pretensão de direito substancial.

A fonte normativa própria incidente nessa relação jurídica é o art. 39, da Lei no 4.320/1964:

Art. 39. Os créditos da Fazenda Pública, de natureza tributária ou não tributária, serão escriturados como receita do exercício em que forem arrecadados nas respectivas rubricas orçamentárias.

$\S 1^{\circ}$ - Os créditos de que trata este artigo, exigíveis pelo transcurso do prazo para pagamento, serão inscritos, na forma da legislação própria, como Dívida Ativa, em registro próprio, após apurada a sua liquidez e certeza, e a respectiva receita será escriturada a esse título.

$\S 2^{\circ}$ - Dívida Ativa Tributária é o crédito da Fazenda Pública dessa natureza, proveniente de obrigação legal relativa a tributos e respectivos adicionais e multas, e Dívida Ativa não Tributária são os demais créditos da Fazenda Pública, tais como os provenientes de empréstimos compulsórios, contribuições estabelecidas em lei, multa de qualquer origem ou natureza, exceto as tributárias, foros, laudêmios, aluguéis ou taxas de ocupação, custas processuais, preços de serviços prestados por estabelecimentos públicos, indenizações, reposições, restituições, alcances dos responsáveis definitivamente julgados, bem assim os créditos decorrentes de obrigações em moeda estrangeira, de subrogação de hipoteca, fiança, aval ou outra garantia, de contratos em geral ou de outras obrigações legais.

Então, pode-se afiançar que os créditos não tributários decorrem de quaisquer débitos de terceiros perante a Fazenda Pública, os quais têm sua gênese em obrigações vencidas e previstas em lei, regulamento ou contrato, não possuindo natureza tributária. Um desses exemplos é o crédito derivado do uso oneroso de bem público. ${ }^{1}$

VITTA, Manoel Álvares; GARCIA, Heraldo; SOUZA, Maria Helena Rau de; CÂMERA, Miriam Costa Rebollo; e SAKAKIHARA, Zuudi. FREITAS, Vladimir Passos de (Coord.). Execução fiscal: doutrina e jurisprudência. São Paulo: Saraiva, 1998. p. 20. 
Nesse sentido, tendo em vista que conceito de dívida ativa abarca também os débitos de qualquer natureza, todas as fontes de receita da Fazenda Pública, respeitados os atributos de certeza e liquidez, podem configurar créditos passíveis de execução fiscal, na forma da Lei nº 6.830, de 22 de setembro de 1980. Para tanto, é indispensável a prévia e regular inscrição em dívida ativa, com o cumprimento de todas as formalidades legais.

Assim, é evidente que o crédito dessa natureza deve ser reputado como dívida não tributária, relegada, então, a uma disciplina normativa específica. ${ }^{2}$ Isso porque os montantes decorrentes da utilização do patrimônio estatal são típicas dívidas administrativas, sem fundo tributário.

Na ausência de uma legislação local ou regional que compreenda um procedimento administrativo específico à espécie, podemos detalhar alguns parâmetros a serem seguidos pelo gestor público municipal ou estadual, quando da cobrança administrativa. A constituição de um crédito em favor da Fazenda Pública consiste em um procedimento vinculado e obrigatório, garantindo, na mesma medida, o respeito aos direitos fundamentais. Logo, a finalidade principal desse procedimento é constituir a liquidez e a certeza da dívida, até para dar azo à inserção desse crédito em título executivo extrajudicial.

Dessa forma, uma lógica básica pode ser aplicada ao caso em pauta, ou seja, às dívidas não tributárias em favor dos estados, dos municípios ou do Distrito Federal, quando ausentes regras específicas voltadas a essa situação:

$1^{\circ}$ ) verificação da existência da hipótese de incidência, ou seja, da presença de um direito de crédito constituído em favor da Fazenda Pública, derivada da lei ou de um contrato;

$\left.2^{\circ}\right)$ verificação da ocorrência concreta e específica do fato gerador não tributário, ou seja, que o fato concreto efetivamente ocorreu;

3ํ) verificação se não houve quitação voluntária do devedor;

$\left.4^{\circ}\right)$ notificação do devedor para ciência do débito, concedendo-lhe prazo para, querendo, impugnar a obrigação imputada;

$5^{\circ}$ ) caso exista impugnação administrativa, esta deve ser instruída e julgada, sendo observados os parâmetros do devido processo legal, especialmente o direito à ampla defesa e ao contraditório (art. 5o, inciso $\mathrm{LV}$, da CF/88);

2 Perceba que o próprio art. 139, do CTN, dá cabo de fornecer uma resposta exata à espécie: “O crédito tributário decorre da obrigação principal e tem a mesma natureza desta". 
$\left.6^{\circ}\right)$ o crédito deve ser, então, constituído definitivamente, sendo o devedor notificado deste ato administrativo;

(Obs.: a segunda notificação é necessária, independentemente de o devedor ter ofertado defesa ou ter permanecido inerte. O crédito considera-se constituído após o primeiro dia útil posterior ao término do prazo de defesa). ${ }^{3}$

Ademais, destaca-se que a constituição definitiva do crédito será o marco divisório entre os prazos de decadência e de prescrição, ou seja, o primeiro corre até esse evento, e o segundo inicia a partir dele. Sistematizando, pode-se dizer que a decadência terá como ponto de partida a ocorrência do fato gerador e, como termo final, constituição definitiva do crédito. Já a prescrição começa a fluir a partir desse último evento, e termina com o exercício da pretensão. Dessa forma, a minuta do procedimento ora sugerido aos entes federados que não possuem legislação específica sobre o tema pode ser demonstrada de modo didático da seguinte maneira:

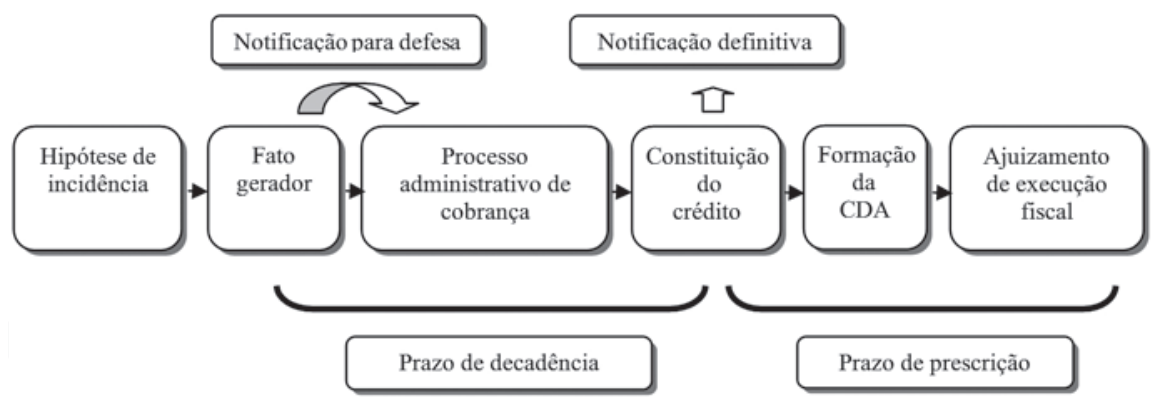

Assim, o fluxograma apresentado pode ser aplicado no limiar do procedimento de constituição e cobrança dos créditos derivados do uso oneroso de bem público. A inscrição em dívida ativa pode, claro, seguir rito específico disposto por normas administrativas pertinentes, desde que compatível com as observações feitas no que se refere ao respeito às garantias fundamentais. Por fim, importante mencionar que o referido montante devido deverá ser inscrito em dívida ativa e poderá ser cobrado pela via judicial regulada pela Lei ํo 6.830/1980.

3 A segunda notificação é exigida pela jurisprudência: STJ, REsp. 1.015.297, rel. min. José Delgado, Corte Especial, j. 22-4-2008. 
Em termos objetivos, intenciona-se conceber um esboço de rotina administrativa para a cobrança dos créditos não tributários por aqueles entes federados que não possuem legislação específica. Para tanto, foi estabelecido um marco legal a partir da legislação federal que disciplina o tema.

\section{Decadência e prescrição incidentes}

No Brasil, era obscura a distinção e, por conseguinte, a aplicação de prazos prescricionais e decadenciais, dada a confusão gerada pelas disposições (ou pela falta delas) do Código Civil de 1916, ${ }^{4}$ até a publicação do célebre artigo de autoria de Agnelo Amorim Filho. ${ }^{5}$ Em seu trabalho, o jurista fez uma associação entre a prescrição e decadência e as respectivas cargas de eficácia das ações processuais, vinculando a primeira às ações condenatórias (relacionadas a direitos subjetivos), restando a última associada a direitos potestativos e às ações constitutivas, negativas ou positivas.

Antes disso, foi a partir da monografia de Windscheid que a noção de prescrição tomou corpo e passou a estar arraigada no direito material. A ideia do Klageverjährung ${ }^{6}$ cedeu espaço à compreensão de que a prescrição atinge a exigibilidade, ou seja, está catalogada na seara do direto substantivo (Anspruchsverjärung). Tanto é verdade que o Bürgerliches Gesetzbuch (BGB) ${ }^{7}$ acabou por expressamente conceber a concepção de pretensão em seu bojo (Anspruch), ${ }^{8}$ o que, por consequência, fez surgir um dispositivo específico sobre a prescrição, qual seja, o $§ 199 .^{9}$

Nesse contexto, teria a prescrição “(...) relação com deveres, obrigações e com a responsabilidade decorrente da inobservância das regras ditadas pelas partes ou pela ordem jurídica". A decadência, ao revés, referir-se-ia a "(...) um estado de sujeição, próprio dos direitos potestativos". ${ }^{10}$ Essa orientação foi

4 TARTUCE, Flávio. Manual de direito civil. Rio de Janeiro: Forense; São Paulo: Método, 2012. p. 258.

5 AMORIM FILHO, Agnelo. Critério científico para distinguir a prescrição da decadência e para identificar as ações imprescritíveis. Revista de Direito Processual Civil, São Paulo, v. 3, p. 95-132, jan./jun. 1961.

6 Expressão que pode ser traduzida como sendo um instituto jurídico limitador ao exercício de uma ação.

7 Código Civil alemão.

8 BGB, §194.

9 TONIOLO, Ernesto José. A prescrição do crédito fiscal e seus fundamentos constitucionais. Revista da Procuradoria-Geral do Estado, Porto Alegre, v. 32, n. 68, p. 16, jul./dez. 2011.

$10 \quad$ Ibid., p. 259. 
conspícua e sapientemente adotada pelo Código Civil de 2002, ${ }^{11}$ cuja base está justamente no BGB germânico - mencionado anteriormente - , dando vazão ao paradigma da operabilidade, visando a facilitar a utilização do sistema jurídico vigente. ${ }^{12}$

O Código Civil atual, então, com o fito de indicar não se tratar de um direito subjetivo público, perfilhou a tese da prescrição da pretensão. ${ }^{13}$ Reza o seu art. 189: "Violado o direito, nasce para o titular a pretensão, a qual se extingue, pela prescrição, nos prazos a que aludem os arts. 205 e 206 ". ${ }^{14}$

Apenas os direitos subjetivos patrimoniais submetem-se à prescrição, por conferirem, ao titular, uma pretensão de exigir, de outrem, determinado comportamento, sendo este "apreciável economicamente". Quando não é executada voluntariamente a conduta esperada, poderá ser exercida a pretensão do titular. O prazo prescricional tem início com o surgimento da pretensão, que decorre da exigibilidade do direito subjetivo. Seu transcurso pode ser impedido, suspenso e/ou interrompido, conforme previsão legal.

A decadência, ao seu tempo, também chamada de caducidade, faz perecer o próprio direito, atingindo-o na essência. ${ }^{15}$ Tal instituto encontra origem na lei (decadência legal), mas pode ser estabelecido mediante convenção entre as partes (decadência convencional), no exercício da autonomia privada. Aos prazos decadenciais não se aplicam, salvo exceção prevista expressamente em lei, as normas que impedem, suspendem ou interrompem a prescrição. ${ }^{16}$

11 Ibid.

12 FARIAS, Cristiano Chaves de; ROSENVALD, Nelson. Direito civil: teoria geral. Rio de Janeiro: Lumen Juris, 2009. p. 637.

13 Flávio Tartuce, Manual de direito civil, op. cit., p. 261. "A prescrição extintiva, fato jurídico em sentido estrito, constitui nesse contexto, uma sanção ao titular do direito violado, que extingue tanto a pretensão positiva quanto a negativa (exceção ou defesa). Trata-se de um fato jurídico stricto sensu justamente pela ausência de vontade humana, prevendo a lei efeitos naturais, relacionados com a extinção da pretensão. A sua origem está no decurso do tempo, exemplo típico de fato natural. Na prescrição, nota-se que ocorre a extinção da pretensão; todavia, o direito em si permanece incólume, só que sem a proteção jurídica para solucioná-lo." (Ibid.).

14 Além disso, importante notar que a prescrição admite uma dualidade conceitual em que estão compreendidas as noções de extinção de situações jurídicas - chamada prescrição extintiva - e de consolidação de relações que se perpetuam no tempo - a prescrição aquisitiva. (Cristiano Chaves de Farias e Nelson Rosenvald, Direito civil, op. cit., p. 638).

15 "A decadência está atrelada, fundamentalmente, aos direitos potestativos. É que sendo exercidos através de mera manifestação de vontade do próprio titular, independendo da submissão de terceiros, inadmitem os direitos potestativos violação e, via de consequência, não trazem consigo pretensão (típica dos direitos subjetivos - que, por isso, submetem-se a prazos prescricionais). Ora, em se tratando de um direito potestativo - e, por conseguinte, cujos efeitos podem ser obtidos diretamente pela manifestação de vontade do titular - não se pode falar em prescrição (que, por sua vez, é a perda da pretensão de exigir de alguém um comportamento). O exercício dos direitos potestativos depende, tão só, da vontade de seu próprio titular." (Ibid., p. 668).

16 Flávio Tartuce, Manual de direito civil, op. cit., p. 277. 
Especificamente em direito administrativo, a dicotomia entre prescrição e decadência não é tranquila. E a influência do direito alemão contribuiu para isto, porque ele não distingue entre prescrição e decadência (tudo se baseia no instituto da verjährung). Mesmo os franceses não apresentam a dicotomia entre prescrição e decadência, porque só tratam a matéria sob a rubrica da prescrição. ${ }^{17}$ Contudo, no Brasil, a distinção veio plasmada de forma completamente desestruturada, ou seja, casuisticamente e sem qualquer sistematicidade. $^{18}$

O que importa notar é que o direito administrativo nacional, apesar de toda a confusão estabelecida pelas normas jurídicas, admite bem o convívio de ambos os institutos jurídicos, e mesmo concomitantemente, como se pode ver a partir da dicção do art. 47, da Lei nº 9.636/1998. E outros exemplos podem ser fornecidos: no âmbito da violação de prestações em contratos e na seara da responsabilidade civil extracontratual, está-se a tratar de casos de prescrição, uma vez que a pretensão a ser obtida via juízo possui carga de eficácia predominantemente condenatória a uma prestação da outra parte. Enquanto a anulação dos atos administrativos submete-se, como dito, à caducidade do direito.

A rigor, poder-se-ia pensar que inexiste prescrição no direito administrativo, porque as regras até agora existentes estabelecem, em suma, a perda de direito, e não mera extinção de uma pretensão. Contudo, como visto, isso não procede. Em inúmeros casos o ordenamento jurídico disciplinou, de forma expressa, prazos de prescrição relacionados à relação jurídico-administrativa (v.g., Decreto-Lei no 20.910/1932). Veja que, no caso, será a estrutura do suporte fático de cada categoria jurídica quem fará previsão de um prazo de decadência ou de prescrição, ou de ambos, até porque não importa o nomen juris conferido pela legislação.

Há casos em que se percebe, claramente, na linha do direito tributário, por exemplo, dois momentos bem distintos: uma sucessão de atos para a constituição do crédito, bem como, posteriormente, uma etapa muito distinta que se assenta na sucessão de atos para o exercício de pretensão desse crédito. Assim, ter-se-iam constituídos dois prazos: um de decadência e outro de prescrição.

17 Por todos: WALINE, Marcel. Précis de droit administratif. Paris: Montchrestien. v. 1, p. 389.

18 Veja que os Decretos no 20.910/1932 e no 4.597/1942 apontam que a administração pública se submete a prazos de prescrição, sem mencionar qualquer prazo de decadência a respeito. Mais recentemente, a Lei no 9.784/99 (art. 54) apenas traz, ao bojo do seu texto, prazo de decadência, sem fomentar qualquer disciplina jurídica sobre a prescrição. 
E os créditos decorrentes do uso oneroso de bem público bem refletem esta dualidade: geram um crédito à administração pública, que deve, primeiro, constituí-lo e, depois, cobrá-lo, na forma do que foi estabelecido no âmbito federal - Lei oㅗ 9.636/1998. Surge, aqui, verdadeiro procedimento administrativo de constituição da receita (liquidação do crédito), lançamento em dívida ativa e, depois disso, sucessiva cobrança. Originam-se, então, dois prazos distintos para o exercício do direito e da pretensão, ou seja, percebe-se que, nesse caso, convivem, paralelamente, a decadência e a prescrição.

Em conclusão a esse tópico: no caso de cobrança de créditos não tributários, como aqueles derivados do uso oneroso de bem público, percebe-se que podem conviver, de maneira concomitante, os prazos de decadência e de prescrição. Para tanto, foi exposto um esboço de como deveria ser estruturado o procedimento administrativo de cobrança dessas receitas.

\section{Lacuna normativa. Incidência da Lei federal no 9.636/1998. Postulado da segurança jurídica como marco hermenêutico ao caso concreto}

A segurança jurídica, possivelmente, seja um dos temas do direito que mais tenham, na atualidade, rendido textos doutrinários e debates nos tribunais brasileiros. E o tema não se esgota, porque, contemporaneamente, a segurança jurídica acaba perpassando todas as relações jurídicas. A garantia generalizada e congruente das expectativas de comportamento originadas no seio das interações sociais sempre teve o direito como seu fiador. Sua finalidade era justamente causar uma minimização da contingência das ações individuais, possibilitando que cada um possa esperar, com um mínimo de certeza e garantia, o comportamento do outro. ${ }^{19}$

Percebe-se que o mundo atual é marcado pela desconfiança. E a administração pública tende, assim, a resgatar uma necessária aproximação para com os administrados, realçando valores como a transparência, a valorização

19 "O direito vigente garante, de um lado, a implementação de expectativas de comportamento sancionadas pelo Estado e, com isso, segurança jurídica; de outro lado, os processos racionais da normatização e da aplicação do direito prometem a legitimidade das expectativas de comportamento assim estabilizadas - as normas merecem obediência jurídica e devem poder ser seguidas a qualquer momento, inclusive por respeito à lei." (HABERMAS, Jürgen. Direito e democracia: entre facticidade e validade. Rio de Janeiro: Tempo Brasileiro, 1997. v. 1, p. 246). 
da boa-fé, da manutenção das expectativas legítimas etc. ${ }^{20}$ Tais meios procuram deixar menos complexas as relações postas em conflito. ${ }^{21}$

O Estado, nesse sentido, em “(...) quaisquer de seus atos - tanto mais porque cumpre a função de ordenador da vida social - tem de emergir como interlocutor sério, veraz, responsável, leal e obrigado aos ditames da boa-fé" ${ }^{22}$ E quanto aos administrados: "De seu turno, os administrados podem agir fiados na seriedade, responsabilidade, lealdade e boa-fé do Poder Público, maiormente porque a situação dos particulares é, em larguíssima medida, condicionada por decisões estatais, ora genéricas, ora provenientes de atos concretos". ${ }^{23}$

O próprio Kelsen antecipava que os tribunais poderiam atuar na maximização da segurança jurídica. ${ }^{24}$ A questão pode ser posta na pergunta feita por Habermas: “O problema da racionalidade da jurisprudência consiste (...) em saber como a aplicação de um direito contingente pode ser feita internamente e fundamentada racionalmente no plano externo, a fim de garantir simultaneamente a segurança jurídica e a correção". ${ }^{25}$ Uma das respostas encontradas pelo autor baseia-se no seguinte entendimento: "Os paradigmas se coagulam em ideologias, na medida em que se fecham sistematicamente contra novas interpretações da situação e contra outras interpretações de direitos e princípios, necessárias à luz de novas experiências históricas" ${ }^{26}$

20 “O ordenamento jurídico protege a confiança suscitada pelo comportamento do outro e não tem mais remédio que protegê-la, porque poder confiar (...) é condição fundamental para uma pacífica vida coletiva e uma conduta de cooperação entre os homens e, portanto, da paz jurídica." (LARENZ, Karl. Derecho justo: fundamentos de ética jurídica. Madri: Civitas, 1985. p. 91).

21 Como bem refere Jesús Gonzales Pérez: "En el ámbito del Derecho administrativo, el principio de buena fe ha permitido otorgar al administrado una protección similar a la que ha otorgado fuera no nuestro Ordenamiento jurídico el principio de confianza legítima. Quizás, después de muchos esfuerzos, puedan, extremando la pulcritud de conceptos, encontrar esferas a las que no llega la protección del principio da la confianza legítima y sí el da la buena fe, y esferas a las que no llega la protección de éste, pero sí el de aquél. Pero siempre podrá la jurisprudencia utilizar uno u otro para extender debidamente la protección de la confianza legítima, de modo que no quede inmune ningún ámbito de las relaciones. Al fin y al cabo es lo que hizo nuestra jurisprudencia antes de la recepción formal del principio de la confianza legítima." (GONZALEZ PÉREZ, Jesús. El principio general de la buena fe en el derecho administrativo. Madri: Civitas, 1989. p. 54).

22 MELLO, Celso Antônio Bandeira de. Segurança jurídica, boa-fé e confiança legítima. Revista Trimestral de Direito Público, São Paulo, n. 51-52, p. 7, s.d.

23 Ibid.

24 "A Criação de normas jurídicas gerais pelos tribunais: o juiz como legislador; flexibilidade do Direito e segurança jurídica." (KELSEN, Hans. Teoria pura do direito. São Paulo: Martins Fontes, 1995. p. 274). Além disso, o autor austríaco conclui que: “(...) o tribunal que cria o precedente funciona como legislador, talqualmente o órgão a que a Constituição confere poder para legislar" (Ibid., p. 278).

25 Jürgen Habermas, Direito e democracia, op. cit., p. 247.

26 Ibid., p. 275. 
Daí por que se conclui que a segurança jurídica passa, especialmente no período contemporâneo, a fazer parte do cotidiano das relações jurídico-

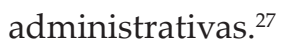

O princípio da estabilidade das relações jurídicas, sendo um aspecto do chamado princípio da segurança jurídica, possui fundamento naquilo "(...) sobre que se apoia quer um dado domínio do ser, quer uma teoria ou um conjunto de conhecimentos (e então o fundamento é o conjunto de proposições das quais esses conhecimentos se deduzem)", ${ }^{28}$ ao ponto de ser considerado elemento nodal no estado de direito. ${ }^{29}$ Modernamente, o fundamento máximo da segurança jurídica não está na legalidade estrita, ${ }^{30}$ mas sim assenta-se no seio dos direitos fundamentais, dada sua força normativa conferida pela jurisdição constitucional. ${ }^{31}$ E esse giro hermenêutico modifica substancialmente a forma de encarar as fontes desse instituto. ${ }^{32}$

Não é à toa que este é “(...) um valor constitucional que se qualifica como subprincípio do princípio maior do Estado de Direito, ao lado e no mesmo nível hierárquico do outro subprincípio do Estado de Direito, que é o da legalidade. Segurança jurídica e legalidade são, sabidamente, os dois pilares de sustentação do Estado de Direito". ${ }^{33}$ Impõe-se, pois, que a legalidade seja

27 PEREZ, Jesus Gonzalez. El principio general de la buena fe en el derecho administrativo. Madri: Civitas, 1989. p. 89. Ainda, consultar a obra de: BIGOLIN, Giovani. Segurança jurídica: a estabilização do ato administrativo. Porto Alegre: Livraria do Advogado, 2007.

28 CALMES, Sylvia. Du principe de protection de la confiance légitime en droits allemand, communautaire et français. Paris: Dalloz, 2001. p. 166.

29 O estado de direito possui as seguintes características: (a) existência de mecanismos de participação no procedimento de formação do ato administrativo; (b) imperiosa a motivação do ato administrativo; (c) dever de informação; (d) existência de recursos e de (e) notificações - ciência do ato ou decisão administrativa (CORREIA, Fernando Alves. Alguns conceitos de direito administrativo. Coimbra: Almedina, 2001. p. 10). No mesmo sentido: STF, MS 24.268MG, rel. min. Ellen Gracie, rel. para o acórdão min. Gilmar Mendes, Pleno, j. 5-2-2004. No STF, MS 24.781-DF, Pleno, relator p/ Acórdão min. Gilmar Mendes, DJe de 8-6-2011, o ministro Gilmar Mendes se manifestou no sentido de que “(...) é nessas hipóteses que incide o princípio da segurança jurídica, como subprincípio do Estado de Direito, no sentido da proteção das situações jurídicas criadas pelo Poder Público e estabilizadas pelo transcurso do tempo em que o próprio Poder Público quedou-se inerte".

30 Não que a legalidade deixe de ser um fundamento à segurança jurídica, mas perde o papel principal nesse sentido.

31 Tanto que Heleno Taveira Torres (Direito constitucional tributário e segurança jurídica: metódica da segurança jurídica do sistema constitucional tributário. São Paulo: Revista dos Tribunais, 2011. p. 186-187) considera que a segurança jurídica seria uma espécie de garantia material para a concretização de direitos e liberdades fundamentais. Tem por base três elementos: certeza, estabilidade sistêmica e proteção às expectativas de confiança legítimas.

32 STF, Pet 2.900 QO-RS, rel. min. Gilmar Mendes, Segunda Turma, j. 27-5-2003.

33 SILVA, Almiro do Couto. O princípio da segurança jurídica (proteção à confiança) no direito público brasileiro e o direito da administração pública de anular seus próprios atos administrativos: o prazo decadencial do art. 54 da Lei do processo administrativo da União (Lei no 9.784/99). Revista da Procuradoria-Geral do Estado, n. 57, p. 35-78, dez. 2003. 
ponderada com outros valores constitucionais não menos relevantes, como a segurança jurídica. Não se pode, portanto, ver a atuação do Estado dissociada desse paradigma.

Humberto Ávila, ao seu turno, destacou que a expressão "segurança jurídica" pode ter variados sentidos. Para tanto, adota dois critérios nesse sentido: quanto ao fim ou quanto ao fundamento. ${ }^{34}$ Para o autor, o instituto em foco deve dar lugar à controlabilidade semântica-argumentativa, em vez de se optar por preencher o conteúdo por meio de determinação normativa. Isso porque a segurança não deve ser um bem retirado do ordenamento jurídico, mas sim originar-se a partir de processos de legitimação, argumentação e de fundamentações normativas. ${ }^{35}$

Um julgado importante na construção do primado desse instituto jurídico é encontrado no arrêt Cachet, exarado pelo Conselho de Estado francês, em 1923. Em verdade, o direito daquele país encara a segurança jurídica a partir da sua dicotomia para com a legalidade. E é desse conflito que surgiram as bases do instituto em questão. E uma apresentação muito clara dessa dialética pode ser vista, como dito, no famoso caso "affaire Dame Cachet". Então, a partir dessa data, em França, firmou-se o entendimento no sentido de que o direito que a administração pública tem de anular de ofício seus próprios atos decai no mesmo prazo que o cidadão tem para questionar o tal vício, o que se faz por meio de recurso contencioso. O prazo para promover a referida medida era fixado em dois meses. Assim, o aresto francês colocou limites ao livre exercício, pelo poder público, de anular os próprios atos, fixando balizas nesse sentido. ${ }^{36}$

Modernamente, então, com lastro em vários eventos, estruturou-se a administração pública em um padrão dialógico. Ao atingir esse patamar, o Estado passou a promover inúmeros mecanismos que viabilizavam o diálogo entre todos os sujeitos que se relacionavam com o poder público. ${ }^{37}$ Importante

34 ÁVILA, Humberto. Segurança jurídica. Entre permanência, mudança e realização no direito tributário. São Paulo: Malheiros, 2011. p. 122-138.

35 Ibid., p. 279.

36 Na Alemanha, o princípio da confiança legítima estrutura-se principalmente a partir da decisão do Tribunal Administrativo de Berlim, de 14 de novembro de 1956 (DVBL 1957, 503) - BVerwGE 9, 251. Na Argentina, a jurisprudência consagrou os requisitos da estabilidade administrativa no caso Carman de Cantón, em 1936.

37 A administração pública dialógica atende ao "princípio da boa administração", sendo essa premissa dissecada, entre nós, por Juarez Freitas (Discricionariedade administrativa e direito fundamental à boa administração. São Paulo: Malheiros, 2007). O autor defende que a boa administração impõe que esta seja dialógica, porque exige a manutenção do contraditório e da ampla defesa, consectários do devido processo (Ibid., p. 20). 
dizer que o dialogismo é exercido por ferramentas jurídicas espalhadas no texto constitucional.

Já no limiar da administração pública brasileira, a segurança jurídica cumpre um papel essencial. Tanto que o art. 2º, caput, da Lei no 9.784/1999 (Lei do Processo Administrativo Federal) deu cabo de positivar a segurança jurídica como uma diretriz de observância obrigatória. ${ }^{38}$ Esse valor está ligado a inúmeros outros institutos, que nada mais são do que a ferramentaria jurídica para se alcançar esse bem juridicamente tutelado. Em verdade, recorre-se a esses instrumentos para conferir efetividade à segurança das relações (v.g., ao instituto da decadência, da prescrição ou da preclusão administrativas).

Nesse exemplo, esses institutos jurídicos devem ser aplicados quando se pretende manter situações que foram, ao longo do tempo, consolidadas, ofertando efeitos benéficos a alguém. As regras de decadência ou de prescrição, assim, procuram ofertar um nivelamento nos estágios de afronta a direitos. ${ }^{39}$ Dessa perspectiva, um dos pontos cardeais do dito balanceamento de valores constitucionais que se faz entre a legalidade e a segurança jurídica consiste na fixação da delimitação prazal para que a administração pública exerça a potestade das funções públicas que lhe são afetas. ${ }^{40}$

No presente caso, quando há uma lacuna normativa estadual, municipal e distrital no sentido de dizer qual é o prazo prescricional dos créditos não tributários, como, v.g., ocorre com aqueles oriundos da exploração onerosa de bens públicos, deve se procurar um limite à exação do Estado, em homenagem, como visto, à segurança jurídica. Em outros termos: quando não existe uma lei estadual que diga qual é o prazo de decadência e/ou de prescrição incidente à espécie, deve-se definir um marco à espécie, porque a segurança jurídica impõe que se tenha um limite temporal a essa exação, ou seja, que essas situações não fiquem ao alvedrio de um futuro incerto, de um infinito deletério.

Logo, a tarefa do jurista, nesse caso, consiste em definir qual o prazo de prescrição/decadência incidente à espécie, a ser retirado da legislação

38 Lei no 9.784/1999, art. 2o: “A Administração Pública obedecerá, dentre outros, aos princípios da legalidade, finalidade, motivação, razoabilidade, proporcionalidade, moralidade, ampla defesa, contraditório, segurança jurídica, interesse público e eficiência".

39 Exemplo ofertado por COSTA, Judith Martins. Almiro do Couto e Silva e a ressignificação do princípio da segurança jurídica na relação entre o Estado e os cidadãos. In: ÁVILA, Humberto. (Org.). Fundamentos do estado de direito: estudos em homenagem ao professor Almiro do Couto e Silva. São Paulo: Malheiros, 2005. p. 123.

40 MAFFINI, Rafael Da Cás. Atos administrativos sujeitos a registro pelos Tribunais de Contas e a decadência da prerrogativa anulatória da administração pública. Revista Brasileira de Direito Público - RBDP, Belo Horizonte, ano 3, n. 10, p. 143-163, jul./set. 2005. 
extravagante, até porque estes institutos jurídicos não podem ser presumidos, porque derivam de norma vigente e regularmente ditada. Nesse caso, os métodos hermenêuticos de integração e de interpretação, como corolários da compreensão jurídica, devem incidir à situação em causa, a fim de dar uma resposta específica ao tema. ${ }^{41}$ Dessa forma, concebe-se que a prática da interpretação, diante do panorama narrado, será compreendida como uma atitude de mediação pela qual o intérprete deverá trazer o não entendimento de um texto a um nível de compreensão. Em outras palavras, interpretar não se resume à mera explicação do significado daquele dispositivo, mas igualmente na construção de um sentido, qual seja, a definição do prazo extintivo incidente à espécie. ${ }^{42}$

A partir daí, filiamo-nos à corrente doutrinária que formula a teoria da coerência e da completude, o que significa dizer que um ordenamento não deve ser interpretado de maneira antagônica, incoerente ou dissociada, ou mesmo possuir essas idiossincrasias. $O$ todo deve ser harmonizado, a fim de evitar que, em um mesmo ordenamento jurídico, coexistam, simultaneamente, duas normas antinômicas, bem como que não existem lacunas no sistema jurídico positivado. ${ }^{43} \mathrm{O}$ conceito de integração, por sua vez, permite que se tragam elementos externos ao ordenamento, para que possam suprir as lacunas existentes. Então, não há um sistema de autointegração, isto é, a completude e a harmonia do complexo de regras não estão prontas e acabadas, mas devem ser (eternamente) construídas, a fim de garantir a autossuficiência do sistema jurídico, sem recorrer a elementos estranhos ao direito. A integração se vale de

41 Nelson Saldanha destaca as diferenças e semelhanças entre o termo "hermenêutica" e o termo "interpretação". Ambos os verbetes designam "(...) o trabalho de entender significações" (Pequeno dicionário da teoria do direito e filosofia política. Porto Alegre: Sérgio Antônio Fabris, 1987. p. 161).

42 HEINEN, Juliano. Interpretação conforme a constituição: análise a partir da doutrina e da jurisprudência. Porto Alegre: Verbo Jurídico, 2011. p. 13. Ainda: "Essas considerações levam ao entendimento de que a atividade do intérprete - quer julgador, quer cientista - não consiste em meramente descrever o significado previamente existente dos dispositivos. Sua atividade consiste em constituir esses significados. Em razão disso, também não é plausível aceitar a ideia de que a aplicação do direito envolve uma atividade de subsunção entre conceitos prontos antes mesmo do processo de aplicação." (ÁVILA, Humberto. Teoria dos princípios: da definição à aplicação dos princípios jurídicos. São Paulo: Malheiros, 2004. p. 24). Ou, para ser mais claro: "Interpretação é, se nos ativermos ao sentido das palavras, 'desentranhamento', difusão e exposição do sentido disposto no texto, mas, de certo modo, ainda oculto" (LARENZ, Karl. Metodologia da ciência do direito. Lisboa: Fundação Calouste Gulbenkian, 1997. p. 441). Conferir, ainda: DEMO, Pedro. Metodologia científica em ciências sociais. São Paulo: Atlas, 1995. p. 247-248.

43 Por todos: BOBBIO, Norberto. O positivismo jurídico: lições de filosofia do direito. São Paulo: Ícone, 1995. p. 132-133. 
elementos exteriores, como as outras fontes jurídicas, tais quais os princípios gerais do direito - não positivados - , a equidade etc. ${ }^{44}$

Portanto, desde já rechaçamos a tese de que, na ausência de normas de prescrição e/ou de decadência, não se teria evidenciado qualquer prazo extintivo para o exercício da constituição do crédito e da pretensão de cobrança. A segurança das relações jurídicas, de acordo com o que foi apresentado, não se compadece com a noção de imprescritibilidade, por exemplo. Assim, não temos dúvidas em afirmar que, no caso, a cobrança desses créditos não pode ser eternizada.

Dessa forma, na ausência de uma regra estadual, municipal ou distrital específica de prescrição e/ou de decadência aplicável ao caso, qual seria o prazo a ser conferido para dar segurança jurídica à matéria? Em resposta, visualizamos dois caminhos possíveis a serem tomados. Apresentamos ambos, e o segundo é aquele que se mostra sistematicamente mais lógico e coerente com a noção de completude do sistema jurídico.

\section{4. "Trilhas jurídicas" a serem seguidas}

Em primeiro lugar, poder-se-ia pensar em aplicar à presente situação, a contrário senso, o art. 1丷, do Decreto-Lei no 20.910/1932, ou seja, o prazo prescricional de cinco anos. O raciocínio, nessa hipótese, daria conta de empregar ao Estado o mesmo prazo que é destinado aos particulares para exigirem suas pretensões da fazenda pública. Então, os cinco anos de prescrição englobariam os atos de constituição e exigência do crédito público.

Veja que o Decreto-Lei no 20.910/1932 se refere a "dívidas passivas" da União, estados e municípios. Todavia, no presente caso, cuida-se de dívida não tributária, enfim, de uma pretensão administrativa dos Estados federados, dos municípios ou do Distrito Federal contra um particular, ou seja, um crédito da administração pública para com um administrado. Logo, o problema dessa tese consiste no fato de que ela esqueceria que, na realidade, a receita em questão possui duas fases muito claras: uma etapa de constituição, seguida da fase de exigência da pretensão, na mesma linha do que ocorre com os créditos tributários. Em síntese, as duas etapas conferem efeitos jurídicos completamente diversos, reclamando prazos extintivos diferentes.

44 MAXIMILIANO, Carlos. Hermenêutica e aplicação do direito. Rio de Janeiro: Forense, 1997. p. 220. 
Na hipótese, a aplicação do prazo de prescrição de cinco anos, pura e simplesmente, afeta tão somente a fase de cobrança (exigibilidade). A etapa constitutiva do crédito deve merecer a incidência de eventual prazo decadencial, o que não existiria, caso se aplicasse pura e simplesmente, como dito, o prazo de cinco anos do art. 1ㅜㅡ, do Decreto-Lei no $20.910 / 1932$. O correto entendimento sobre o tema visualiza que o prazo prescricional terá início somente no momento em que se torna exigível a dívida a ser cobrada, ou seja, no dia seguinte ao do vencimento do prazo para pagamento, quando, então, há a possibilidade de reclamar o crédito não tributário fazendário. Antes disso, correm os prazos de caducidade.

Em linhas gerais, a aplicação a contrário senso da legislação mencionada esqueceria que existem duas fases muito claras nos planos de constituição e exigibilidade dos valores aqui envolvidos. Enfim, negaria, no caso, que existe a necessidade de fazermos frente a um prazo de decadência, cuja concepção é plenamente aceita no âmbito dos vários sistemas jurídicos apresentados - de acordo com a exposição feita no item precedente.

Preliminarmente, concluo, pois, que a situação narrada reclama a incidência de dois prazos distintos: decadência e prescrição, até pela similitude que esse caso tem para com o sistema de direito tributário. Assim, penso que se deve aplicar, por analogia, um sistema normativo que atende ao disposto. E, para tanto, o art. 47, da Lei no 9.636/1998, fornece prazos específicos ao caso em concreto.

Então, indo ao ponto: na ausência de normas administrativas estaduais, municipais ou distritais, que digam quais são os prazos de prescrição elou decadência para a cobrança de créditos não tributários, como aqueles oriundos da ocupação onerosa de bens públicos, poder-se-ia aplicar a legislação federal que disciplina a matéria, no caso, a Lei $n^{0}$ 9.636/1998, e alterações posteriores, tudo em homenagem à segurança jurídica.

Em face da situação narrada, a jurisprudência do Superior Tribunal de Justiça (STJ) oferta uma resposta muito tranquila: é possível aplicar a legislação federal aos estados-membros (e, por consequência lógica, aos municípios e ao Distrito Federal), na ausência de normas de prescrição ou de decadência, conferindo a devida segurança às relações jurídicas. No caso, a Corte Superior está a tratar, mais especificamente, da possibilidade de aplicação do art. 54, da Lei no 9.784/1999, ao âmbito local (não que não tenha permitido a incidência, no âmbito regional ou local, de outros dispositivos da Lei do Processo Administrativo Federal). ${ }^{45}$ E não

45 STJ, AgRg no AREsp 263.635-RS, rel. min. Herman Benjamin, 2a Turma, j. 16-5-2013. Conferir, ainda: STJ, AgRg no RMS 20.038-RS, rel. min. Og Fernandes, 6aㅡ Turma, j. 18-4-2013. 
é de hoje que a referida Corte vem decidindo dessa maneira. ${ }^{46}$ No julgamento do STJ, RMS 16.776-PR, decidido em 25 de maio de 2004, p. ex., o STJ já anunciava a aplicação subsidiária da Lei o 9.784/1999 no âmbito interno dos estados-membros. No caso em questão, o ministro Felix Fischer foi mais além, supriu a lacuna de um prazo não previsto no Regimento Interno do Tribunal de Justiça do Estado do Paraná, aplicando a Lei do Processo Administrativo Federal.

Essa linha hermenêutica benevolente com a interpretação favorável à aplicação da lei federal aos estados, municípios e Distrito Federal diante de um "vazio legal" (local ou regional) é amparada pelo Supremo Tribunal Federal (STF) em decisões concretas. Aliás, a Suprema Corte nem mesmo determina ou se manifesta no sentido de que esses entes federados se sintam compelidos a elaborar, urgentemente, normas próprias. ${ }^{47}$

Então, muitas vezes a Lei federal no 9.784/1999 é aplicada em outras esferas da Federação brasileira, na ausência de uma legislação local ou regional pertinente. Logo, considera-se possível aplicar o mesmo raciocínio à Lei no 9.636/1998, também de natureza federal, tendo por base a segurança jurídica.

Naturalmente, conclui-se que a Lei no 9.636/1998 é ato normativo de natureza federal, porque instaura dispositivos específicos à União, e não a todos os entes federados. Assim, a princípio, não se poderia transportar essa legislação ao âmbito local. Apesar disso, a conclusão (quase que cartesiana) apresentada não vem a ser facilmente aceita. Logo, a partir da mesma lógica aplicada à Lei do Processo Administrativo Federal, consideramos possível a incidência da Lei federal $n^{2}$ 9.636/1998 no âmbito estadual, distrital ou municipal, como paradigma aos prazos-limite de cobrança dos créditos não tributários.

O próprio Almiro do Couto e Silva, ${ }^{48}$ muito embora não admita a aplicação da Lei no 9.784/1999 aos demais entes federados, entende que o art. 54, p. ex., poderia ser um indicativo aos estados e aos municípios na ausência de norma

46 STJ, Resp. 1.148.460-PR, rel. min. Castro Meira, Segunda Turma, j. 19-10-2010; STJ, Resp. 1.200.981-PR, rel. min. Arnaldo Esteves Lima, Primeira Turma, j. 5-10-2010; STJ, RMS 21.070SP, rel. min. Laurita Vaz, julgado em 17-11-2009; STJ, REsp 645.856/RS, rel. min. Laurita Vaz, Quinta Turma, DJ 13-9-2004.

47 STF, Rp 1.153/RS, rel. min. Aldir Passarinho, Pleno, j. 16-5-1985. Conferir, ainda: OLIVEIRA, Antônio Flávio de. Interpretação dos arts. 42 a 49 do Estatuto das microempresas e empresas de pequeno porte. FCGP, ano 6, n. 69, p. 71-77, 2007.

48 Almiro do Couto e Silva, O princípio da segurança jurídica (proteção à confiança) no direito público brasileiro e o direito da administração pública de anular seus próprios atos administrativos, op. cit., p. 74 , itens " 59 " e " 60 ". 
específica. O que significa dizer que, diante da ausência de legislação sobre o tema, pode se buscar, no âmbito da legislação federal (tipicamente voltada à União), um paradigma. ${ }^{49}$

Então, ratificando o raciocínio aqui exposto e de forma singela, entendese possível aplicar a mesma lógica desenvolvida pelas Cortes nacionais, quando da integração feita a partir da Lei federal no 9.784/1999 (Lei do Processo Administrativo Federal) aos demais entes federados, quando eles não tiverem editado regras específicas sobre o caso. Esse panorama deve, portanto, ser transposto à presente situação.

Em melhores termos: quando os estados, os municípios ou o Distrito Federal não editaram lei específica que discipline a situação dos créditos não tributários, ou seja, não há uma regra que diga exatamente qual é o procedimento aplicável à espécie, ou o prazo prescricional ou decadencial para a cobrança destes montantes, podem-se tomar por base, em analogia, as disposições federais sobre o tema. Significa dizer que, no cenário de ausência completa de uma disciplina normativa estadual, distrital ou municipal sobre tais prazos, podem se aplicar, em homenagem à segurança das relações jurídicas, as disposições constantes na Lei no 9.636/1998 (art. 47), e alterações posteriores. $^{50}$

No que se refere ao prazo de decadência, a Lei nº 9.636/1998 regulamentou exatamente a matéria em pauta no âmbito da União. Confira:

Art. 47. O crédito originado de receita patrimonial será submetido aos seguintes prazos: (Redação dada pela Lei no 10.852, de 2004)

I - decadencial de dez anos para sua constituição, mediante lançamento; e (Incluído pela Lei no 10.852, de 2004)

II - prescricional de cinco anos para sua exigência, contados do lançamento. (Incluído pela Lei no 10.852 , de 2004)

$\S 1^{\circ}$ O prazo de decadência de que trata o caput conta-se do instante em que o respectivo crédito poderia ser constituído, a partir do conhecimento por iniciativa da União ou por solicitação do interessado

49 Nesse contexto, a fim de permitir uma coerência conceitual, tomar-se-á por base a obra de Thomas Kuhn, no sentido de definir que paradigma "(...) é aquilo que os membros de uma comunidade partilham e, inversamente, uma comunidade científica consiste em homens que partilham um paradigma" (KUHN, Thomas. A estrutura das revoluções científicas. São Paulo: Perspectiva, 2000. p. 219).

50 Tudo de acordo, como dito, com o mesmo raciocínio praticado em relação à Lei nº 9.784/1999. 
das circunstâncias e fatos que caracterizam a hipótese de incidência da receita patrimonial, ficando limitada a cinco anos a cobrança de créditos relativos a período anterior ao conhecimento. (Redação dada pela Lei no 9.821, de 1999)

§2o Os débitos cujos créditos foram alcançados pela prescrição serão considerados apenas para o efeito da caracterização da ocorrência de caducidade de que trata o parágrafo único do art. 101 do Decreto-Lei no 9.760, de 1946, com a redação dada pelo art. 32 desta Lei. (Redação dada pela Lei no 9.821, de 1999)

Dessa forma, diante da ausência de norma estadual específica - regional ou local -, ou seja, verificada lacuna legislativa, impende buscar uma solução jurídica para a questão na regra mencionada. Até porque não se aplicam à dívida ativa não tributária as regras de prescrição e de decadência previstas no Código Tributário Nacional.

A jurisprudência, ao nosso ver, não confere maior profusão à tese específica desta exposição (v.g., aplicação da Lei no 9.636/98 ao âmbito estadual), ou, por vezes, baralha conceitos e legislações. No Recurso Especial (REsp.) no 1.133.696, de relatoria do ministro Luiz Fux, representativo de controvérsia, o STJ decidiu da seguinte forma a questão posta em debate:

1. O prazo prescricional, para a cobrança da taxa de ocupação de terrenos de marinha, é de cinco anos, independentemente do período considerado, uma vez que os débitos posteriores a 1998 se submetem ao prazo quinquenal, à luz do que dispõe a Lei 9.636/98, e os anteriores à citada lei, em face da ausência de previsão normativa específica, se subsumem ao prazo encartado no art. 1ํㅡㄹ do Decreto-Lei 20.910/1932.

2. A relação de direito material que enseja o pagamento da taxa de ocupação de terrenos de marinha é regida pelo Direito Administrativo, por isso que inaplicável a prescrição delineada no Código Civil.

(a) o prazo prescricional, anteriormente à edição da Lei 9.363/98, era quinquenal, nos termos do art. 1ㅇ, do Decreto 20.910/32;

(b) a Lei 9.636/98, em seu art. 47, institui a prescrição quinquenal para a cobrança do aludido crédito;

(c) o referido preceito legal foi modificado pela Lei 9.821/99, que passou a vigorar a partir do dia 24 de agosto de 1999, instituindo prazo decadencial de cinco anos para constituição do crédito, mediante 
lançamento, mantendo-se, todavia, o prazo prescricional quinquenal para a sua exigência;

(d) consectariamente, os créditos anteriores à edição da Lei nº 9.821/99 não estavam sujeitos à decadência, mas somente a prazo prescricional de cinco anos (art. 1ำ do Decreto no 20.910/32 ou 47 da Lei no 9.636/98);

(e) com o advento da Lei 10.852/2004, publicada no DOU de 30 de março de 2004, houve nova alteração do art. 47 da Lei 9.636/98, ocasião em que foi estendido o prazo decadencial para dez anos, mantido o lapso prescricional de cinco anos, a ser contado do lançamento.

A decisão versa sobre ocupação de terrenos de marinha, portanto, de imóveis pertencentes à União. Para a cobrança destes emolumentos, entendia-se que o prazo prescricional era de cinco anos antes da edição da Lei no 9.636/1998, a partir da interpretação retirada a partir dos dispositivos constantes no Decreto-Lei nº 20.910/1932. E continuou sendo de cinco anos mesmo após a edição da Lei no 9.636/1999; porquanto esse foi o prazo prescricional estabelecido por ela para cobrança de receitas patrimoniais. Até então, não havia previsão de prazo decadencial, que foi estabelecido pela Lei no 9.821/1999. Este último interregno de tempo foi aumentado para dez anos pela Lei no $10.852 / 2004$, só incidindo sobre fatos geradores ocorridos a partir do início de sua vigência. Eis o objeto deste leading case, o que revela uma completa ausência de cognição judicial a respeito do caso em pauta.

Logo, a cobrança de "taxa de ocupação", que, em verdade, tributo não é (apesar de ter a denominação de "taxa"), porque é típica receita oriunda de preço público, tem por base uma relação de direito administrativo. Por isso, não se aplicam à espécie as disposições do Código Civil ou do Código Tributário Nacional.

No âmbito do Tribunal de Justiça do Estado do Rio Grande do Sul, podemos citar a Apelação n⿳o 70026553487, de relatoria do desembagador Marco Aurélio Heinz.

De conformidade com o art. 47 da Lei no 9.636/1998, a cobrança decorrente de receita patrimonial não tributária se sujeita à prescrição quinquenal.

Em todo o caso, a jurisprudência do STJ vem entendendo que, se a relação que deu origem ao crédito em cobrança tem assento no Direito Público, não tem aplicação a prescrição constante do Código Civil. Aplicação do disposto no Decreto no 20.910/1932. 
Ao nosso sentir, a decisão não traz elementos seguros. Ao contrário. Primeiro, declara que o prazo prescricional à cobrança de receitas não tributárias seguirá o que dita o art. 47, da Lei no 9.636/1998, sem, contudo, manifestar categoricamente se incide sobre receitas patrimoniais do estado ou do município. Em um segundo momento, manda aplicar o Decreto-Lei no 20.910/1932, que, diante da aplicação do princípio da simetria, também impõe prazo prescricional (e só prescricional) de cinco anos, tal qual dispõe o art. 47, da lei federal mencionada.

É certo que, até então, não havia diferenças substanciais entre os dois diplomas normativos. A dissonância surgiu, como visto, com as Leis $\mathrm{n}^{\mathrm{o}}$ 9.821/1999 e ํo 10.852/2004, quando foi estabelecido prazo decadencial. Contudo, o julgado não adentra nessa questão, ou seja, não declara se o prazo de decadência de 10 anos é aplicado ao âmbito estadual.

Dessa forma, partindo do mesmo raciocínio conferido à Lei federal no 9.784/1999, consideramos que eventual lacuna encontrada em âmbito normativo estadual, distrital ou municipal pode ser suprida pela Lei federal no 9.636/1998. Destaca-se que a aplicação do citado art. 47 deve seguir as diretrizes temporais definidas pelo STJ:

1. $\mathrm{O}$ art. 47 da Lei $9.636 / 98$ instituiu a prescrição quinquenal para a cobrança da taxa de ocupação de terreno de marinha. A Lei 9.821/99, que passou a vigorar a partir do dia 24 de agosto de 1999, estabeleceu em cinco anos o prazo decadencial para constituição do crédito, mediante lançamento, mantendo-se o prazo prescricional quinquenal para a sua exigência. Com o advento da Lei 10.852/2004, publicada em 30 de março de 2004, houve nova alteração do art. 47 da Lei 9.636/98, para estender o prazo decadencial de cinco para dez anos, mantido o lapso prescricional de cinco anos, a ser contado do lançamento.

2. No período anterior à vigência da Lei 9.636/98, em razão da ausência de previsão normativa específica, deve-se aplicar o prazo de prescrição quinquenal previsto no art. $1^{\underline{0}}$ do Decreto $20.910 / 32$. Orientação da Primeira Seção nos EREsp 961.064/CE, julgado na sessão de 10 de junho de 2009.

3. A relação de direito material que dá origem à taxa de ocupação de terrenos de marinha é regida pelo Direito Administrativo, tornando inaplicável a prescrição de que trata o Código Civil. 
4. Assim, o prazo prescricional para a cobrança da taxa de ocupação de terrenos de marinha é de cinco anos, independentemente do período considerado.

5. Embargos de divergência não providos.

(Emb. de Div. Em Resp. 961.064-CE, rel. min. Teori Albino Zavascki, j. 10-6-2009)

Ademais, deve ser mencionado que, para as relações creditícias constituídas antes da vigência da Lei no 9.636/1998, devem ser aplicados os prazos de prescrição e de decadência constantes no Código Civil, na linha do que já foi decidido pelo STJ: “(...) a) antes da vigência do art. 47 da Lei 9.636/98 (18/05/1998), em sua redação original, a cobrança da taxa de ocupação de terreno da marinha sujeitava-se, enquanto preço público, ao prazo prescricional vintenário estabelecido no Código Civil de 1916" (STJ, Resp. 1.015.297, rel. min. José Delgado, $1^{\text {a }}$ Turma, DJe, 21-5-2008). ${ }^{51}$

Ainda permeando o tema, imperioso ter em mente que o prazo prescricional dos créditos dessa espécie passa por uma suspensão de 180 (cento e oitenta) dias, entre a inscrição em dívida ativa e a execução fiscal. Então, esse período de carência de seis meses deve ser levado em conta à espécie ( $3^{\circ}$ - do art. $2^{\circ}$ da Lei no $\mathbf{0} .830$, de 22 de setembro de $1980^{52}$ ).

Evidentemente que o referido dispositivo se aplica aos créditos não tributários da Fazenda pública, na medida em que a eles não se aplica o lançamento previsto no art. 173, do Código Tributário Nacional, porque, nesse último caso, trata-se de receita oriunda de relação calcada no direito

51 Ou ainda: "ADMINISTRATIVO. TERRENO DE MARINHA. TAXA DE OCUPAÇÃO. PRESCRIÇÃO. - No tocante à taxa de ocupação, trata-se de preço público e não tributo, sendo uma contraprestação que o particular deve pagar à União Federal em virtude da utilização de um terreno de marinha. - Considerando as dívidas discriminadas na Certidão de Dívida Ativa que instrui a execução, as taxas de ocupação ali referidas não se encontram prescritas, haja vista a incidência do prazo de 20 anos previsto pelo Código Civil de 1916. - Apelação conhecida e desprovida" (TRF 4를 Região, 3a Turma, AC 200471010015691/RS, rel. des. Carlos Eduardo Thompson Flores Lenz, DJU, 19-10-2005, p. 1000) (grifou-se).

52 Lei no 6.830/80, art. 2o: “Constitui Dívida Ativa da Fazenda Pública aquela definida como tributária ou não tributária na Lei no 4.320, de 17 de março de 1964, com as alterações posteriores, que estatui normas gerais de direito financeiro para elaboração e controle dos orçamentos e balanços da União, dos Estados, dos Municípios e do Distrito Federal. (...) §3ํํ A inscrição, que se constitui no ato de controle administrativo da legalidade, será feita pelo órgão competente para apurar a liquidez e certeza do crédito e suspenderá a prescrição, para todos os efeitos de direito, por 180 dias, ou até a distribuição da execução fiscal, se esta ocorrer antes de findo aquele prazo". 
tributário. Já as receitas, p. ex., que advêm da exploração onerosa de bem público possuem como pano de fundo o direito administrativo.

1. A suspensão do lapso prescricional de 180 (cento e oitenta) dias prevista no art. 2º $\S^{\S} 3^{\circ}$, da Lei 6.830 somente é aplicável às dívidas de natureza não tributária. Em hipóteses como a dos autos, em que se trata de execução de crédito relativo a Imposto de Renda, a matéria é regulada pelo art. 174 do Código Tributário Nacional. 2. Agravo Regimental não provido (STJ, AgRg no AI no 1.054.859, Segunda Turma, rel. min. Herman Benjamin, j. 14-10-2008).

Dessa forma, o termo inicial do prazo de prescrição, observado o disposto

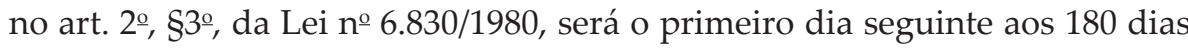
posteriores à inscrição em dívida ativa, salvo se, antes, não se tiver distribuída pertinente execução fiscal. Considerado esse contexto, destaca-se com ênfase que todos os atos tendentes a tornar líquidos e certos tais créditos, assim como os procedimentos relacionados à posterior inscrição em dívida ativa e a consequente propositura da ação de cobrança, se necessária, devem ser ultimados em tais prazos, sob pena de restar caracterizada a consumação da prescrição.

\section{Conclusões}

Diante do exposto, concluo que a constituição de créditos não tributários deve ser feita pela via de procedimento que garanta a incidência dos direitos fundamentais, expondo-se, no corpo deste trabalho, fluxograma específico. A inscrição em dívida ativa seguirá, claro, o rito disposto pelas normas administrativas, desde que compatível com as observações feitas no que se refere ao respeito ao devido processo legal.

Além disso, entendo que a Lei no 9.636/1998, de natureza federal, disciplinou a forma e os prazos prescricionais/decadenciais para a cobrança de créditos não tributários. Contudo, muitos estados e municípios não editaram regras específicas sobre o tema. Assim, na ausência de legislação estadual nesse sentido, devem se aplicar, por analogia, os prazos prescricional e decadencial do art. 47, da Lei nº 9.636/1998, e alterações posteriores, em homenagem à segurança jurídica. Utiliza-se, para tanto, a mesma lógica hermenêutica ofertada à Lei federal no 9.784/1999. 
Importante mencionar que, antes da Lei n 9.636/1998, devem ser aplicados os prazos constantes no Código Civil, ou seja, devem ser observados os lapsos de prescrição previstos no art. 177, da legislação anterior (CC/1916), e no art. 205, do novo Código (2002), observada a regra de transição especificada no artigo 2.028 deste último. Assim, se já transcorrido mais da metade do prazo da lei revogada, estabelecido em 20 anos (art. 177), aplica-se o lapso temporal do Código revogado; se ainda não decorrido tal lapso de tempo, aplica-se o prazo prescricional do novo Código, estabelecido em 10 anos (art. 205), cuja contagem deve ser feita a partir do início da sua vigência. Deve ser dada atenção ao fato de que o termo inicial do prazo prescricional,

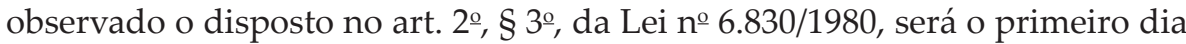
seguinte aos 180 dias posteriores à inscrição em dívida ativa, salvo se, antes, não se tiver distribuída a execução fiscal pertinente.

\section{Referências}

AMORIM FILHO, Agnelo. Critério científico para distinguir a prescrição da decadência e para identificar as ações imprescritíveis. Revista de Direito Processual Civil, São Paulo, v. 3, p. 95-132, jan./jun. 1961.

ÁVILA, Humberto. Segurança jurídica. Entre permanência, mudança e realização no direito tributário. São Paulo: Malheiros, 2011.

BIGOLIN, Giovani. Segurança jurídica: a estabilização do ato administrativo. Porto Alegre: Livraria do Advogado, 2007.

BOBBIO, Norberto. O positivismo jurídico: lições de filosofia do direito. São Paulo: Ícone, 1995.

CALMES, Sylvia. Du principe de protection de la confiance légitime en droits allemand, communautaire et français. Paris: Dalloz, 2001.

CORREIA, Fernando Alves. Alguns conceitos de direito administrativo. Coimbra: Almedina, 2001.

COSTA, Judith Martins. Almiro do Couto e Silva e a ressignificação do princípio da segurança jurídica na relação entre o Estado e os cidadãos. In: ÁVILA, Humberto. (Org.). Fundamentos do estado de direito: estudos em homenagem ao professor Almiro do Couto e Silva. São Paulo: Malheiros, 2005.

DEMO, Pedro. Metodologia científica em ciências sociais. São Paulo: Atlas, 1995. 
FARIAS, Cristiano Chaves de; ROSENVALD, Nelson. Direito civil: teoria geral. Rio de Janeiro: Lumen Juris, 2009.

FREITAS, Juarez. Discricionariedade administrativa e direito fundamental à boa administração. São Paulo: Malheiros, 2007.

HABERMAS, Jürgen. Direito e democracia: entre facticidade e validade. Rio de Janeiro: Tempo Brasileiro, 1997. v. 1.

HEINEN, Juliano. Interpretação conforme a constituição: análise a partir da doutrina e da jurisprudência. Porto Alegre: Verbo Jurídico, 2011

KELSEN, Hans. Teoria pura do direito. São Paulo: Martins Fontes, 1995.

KUHN, Thomas. A estrutura das revoluções científicas. São Paulo: Perspectiva, 2000.

LARENZ, Karl. Derecho justo. Fundamentos de ética jurídica. Madri: Civitas, 1985.

1997. Metodologia da ciência do direito. Lisboa: Fundação Calouste Gulbenkian,

MAFFINI, Rafael Da Cás. Atos administrativos sujeitos a registro pelos Tribunais de Contas e a decadência da prerrogativa anulatória da administração pública. Revista Brasileira de Direito Público - RBDP. Belo Horizonte, ano 3, n. 10, p. 143-163, jul./set. 2005.

MAXIMILIANO, Carlos. Hermenêutica e aplicação do direito. Rio de Janeiro: Forense, 1997.

MELLO, Celso Antônio Bandeira de. Segurança jurídica, boa-fé e confiança legítima. Revista Trimestral de Direito Público, São Paulo, n. 51-52, s.d.

PÉREZ, Jesús Gonzales. El principio general de la buena fe en el derecho administrativo. Madri: Civitas, 1989.

SALDANHA, Nelson. Pequeno dicionário da teoria do direito e filosofia política. Porto Alegre: Sérgio Antônio Fabris, 1987.

SILVA, Almiro do Couto. O princípio da segurança jurídica (proteção à confiança) no direito público brasileiro e o direito da administração pública de anular seus próprios atos administrativos: o prazo decadencial do art. 54 da Lei do processo administrativo da União (Lei no 9.784/99). Revista da Procuradoria-Geral do Estado, n. 57, p. 35-78, dez. 2003. 
TARTUCE, Flávio. Manual de direito civil. Rio de Janeiro: Forense; São Paulo: Método, 2012.

TONIOLO, Ernesto José. A prescrição do crédito fiscal e seus fundamentos constitucionais. Revista da Procuradoria-Geral do Estado, Porto Alegre, v. 32, n. 68, jul./dez. 2011.

TORRES, Heleno Taveira. Direito constitucional tributário e segurança jurídica: metódica da segurança jurídica do sistema constitucional tributário. São Paulo: Revista dos Tribunais, 2011.

VITTA, Manoel Álvares; GARCIA, Heraldo; SOUZA, Maria Helena Rau de; CÂMERA, Miriam Costa Rebollo; SAKAKIHARA, Zuudi; FREITAS, Vladimir Passos de (Coord.). Execução fiscal: doutrina e jurisprudência. São Paulo: Saraiva, 1998. 